\title{
The concept of balanced development of waste management
}

\author{
Anna Starodubova ${ }^{1, *}$, Dilbar Sultanova ${ }^{1}$, and Albert Karimov ${ }^{2}$ \\ ${ }^{1}$ Kazan National Research Technological University, Department of innovation in chemical technology, 420015, Kazan, Russia \\ ${ }^{2}$ Ministry of Industry and Trade of the Republic of Tatarstan, 420111, Kazan, Russia
}

\begin{abstract}
The authors propose the evaluation of the level of development of waste management and the factors associated with effectiveness of waste management in the world. Scientific novelty consists in new principle of the selection of factors. This principle based on the balance between the rate of waste generation and the efficiency of utilization, depending on income level in the countries. As a result, the factors affecting the effectiveness of waste management selected and classified by the method of expert evaluation. The algorithms has been proposed for calculate of the indicators of the intensity of waste generation, of the efficiency of utilization, of the balance of waste, of the overall efficiency of waste management. The evaluation of the effectiveness of waste management was applied by method of score of 217 countries of the world for 2018. The study found a correlation between the effectiveness of waste management and the country's per capita income. This evaluation allows classifying countries on the level of per capita income and by the types of balance between the intensity of waste generation and the efficiency of waste utilization. On this basis the authors proposed to form a balanced policy of waste management.
\end{abstract}

\section{Introduction}

Currently, waste management is a widely discussed topic in the world. The countries of the world recognize the need for effective waste management. Current assessments of waste management focus on waste indicators at the last stage of the product life cycle. This is the "Liquidation" stage. However these assessments of waste management do not take into account waste indicators at the initial stage of the product life cycle. This is the "Production" stage. Countries have insufficient research and expertise on the problem of generation wastes. One of the goals of the concept of the sustainable development of the UN is zero waste by 2030. Therefore, countries need to develop strategies to achieve this goal. This illustrates the relevance of the topic of this study.

The development of the concept of a "Circular economy" in developed countries has made it necessary to find mechanisms that promote the spread of this concept in all countries. However, a clear barrier is the strong differentiation of countries in terms of both income and waste management. Studying the various waste management strategies relative to the level of income of the territory's population.

The purpose of the paper is to study the level of development of waste management and the factors that determine its progress.

The object of the study is waste management strategies of the world's countries.
The subject of this study is the factors affecting the effectiveness of waste management in the world in relation to the level of income of the population.

The hypothesis of the research is that the waste management strategies in countries depend on the level of per capita income. A more effective waste management strategy is achieved in high-income countries. This requires a balance between the rate of waste generation and the efficiency of their utilization.

\section{Materials and methods}

The strategies of waste management progressively evolved as human awareness to environmental impact increases and demonstrate the benefits of proactive waste management measures [1]. An evolutionary leap in waste management has occurred thanks to the concepts of "Sustainable development", "Green economy", "Circular economy", and "Lean production". The development of cleaner production technologies supports the concept of sustainable development by allowing industries to produce more efficiently and gain incredible economic, environmental and social benefits with less input utilization and less environmental impacts [1].

The concept of a "Green economy" is not entirely a new concept. It was first proposed by the London Environmental Economics Centre1 (LEEC) in a publication (Blueprint for a Sustainable Economy) in 1989 authored by David Pearce, Anil Markandya, and Ed Barbier [2]. Since then, many authors have

\footnotetext{
${ }^{*}$ Corresponding author: upfr-nk@list.ru
} 
investigated various aspects of the impact of the "Green economy" concept on socio-economic indicators.

M. Porter and C. Van der Linde emphasize the relationship between competitiveness and the environment [3]. They believe that competitiveness is manifested in regions where the right environmental standards have been developed, which become a source of implementation and continuous improvement of innovations [3]. W. B. Gray also espouses the point of view, that in different regions environmental norms (standards) should be implemented if the benefits to society exceed the costs of their implementation [4]. In those regions where this condition is not met, enterprises tend to move production to regions with less strict regulation [4]. M. Porter and C. Van der Linde believe that in regions where the right environmental standards are introduced before others, they move to the international market before others (with high added value) [3].

Few researchers study the relationship between "Sustainable development" and "Lean production" [5], [6], [7], [8], [9], [10], [11]. T. Larson, R. Greenwood considers them unrelated [12]. Authors A.A. King and M.J. Lenox believe that "Sustainable development" is a positive side effect of "Lean production" (due to the reduction of waste and pollution and efficient use of energy, resources) [13]. As the popularization of "Lean production" grows, many regions are moving to the "Sustainable development". G. G. Bergmiller and P.R. McCright, Ch.M.Kim, H.T. Ming Lim emphasize that regions that implement the "Sustainable development" in the "Lean production" achieve better results than those that do not [14], [15]. Other authors J. D. Hanson, S. Melnyk, R. J. Calantone believe that the introduction of "Sustainable development" and "Lean production" should be carried out simultaneously [16], [17].

Thus, according to the authors, "Lean production" is the driver of the spread of the concept of "Waste management". This hypothesis is true, since Japan, which is a leader in lean management is also a world leader in waste management. On the other hand other factors influencing the development of waste management can be: a high level of pollution of the region strong economic development to increase the growth rate of GRP and the local employment rate. According to research conducted within the framework of the FLAGSHIP project, the development of the waste recycling sector has a potential for GDP growth of $7 \%$ not only through the use of secondary resources and energy recovery, but also the creation of tens of thousands of new jobs.

At the same time, in our opinion, the effectiveness of waste management should strike a balance between the volumes of recycled waste and the waste generated, and the development of recycling plastics and other raw materials should take precedence over primitive incineration of municipal waste for energy.

This study consisted of the following stages.

At the first stage, the classification of factors affecting the effectiveness of waste management was carried out on the basis of the expert assessment method.
At the second stage of the study, algorithms are proposed for calculating summary indicators: the intensity of waste generation, the efficiency of waste utilization, the balance of waste, and the overall efficiency of waste management.

At the third stage of the study, our methodology for evaluating the effectiveness of waste management was applied which consisted of calculating the following indicators: the intensity of waste generation, the efficiency of waste utilization, the balance of waste, and the overall efficiency of waste).

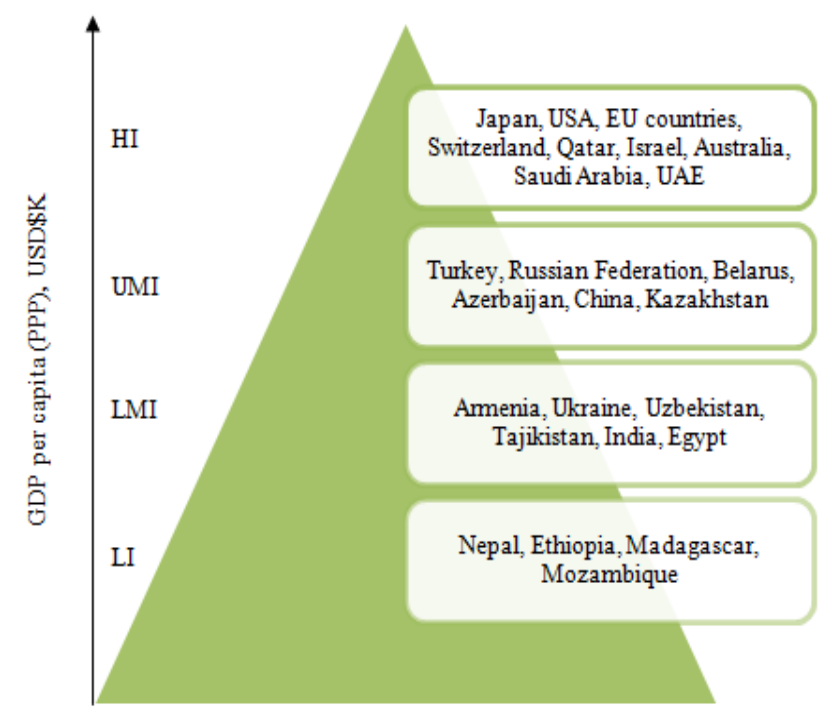

Fig. 1. Examples of countries in the world depending on income in 2018.

Based on the World Bank's "What a Waste 2.0" study, waste in countries was recommended to be analyzed by these indicators: waste generation, structure of waste types, waste collection, utilization methods and costs, number of countries implementing waste laws and recommendations, and characteristics of waste charges by various entities [19].

The World Bank study did reveal a direct relationship between the amount of waste in the world's countries and the GDP per capita factor, as well as factors of urbanization and population size [19]. Therefore, the GDP per capita indicator was chosen by the authors as another classification feature of waste management strategies. This World Bank report, however, did not have an integrated assessment of the world's waste and did not rank each waste indicator. Therefore, the authors included the World Bank's waste indicators (as an expert opinion) as factors affecting waste management.

These indicators of waste management efficiency were classified by the authors into two groups: the intensity of wasted generation and the efficiency of waste utilization. The first group of factors - the intensity of waste generation - is responsible for the inflow of waste from consumers and producers. The second group of factors - utilization efficiency - is responsible for the outflow of waste from consumers and producers. Most methods for evaluating the effectiveness of waste management have been based on indicators 
Table 1. The evaluating the effectiveness of waste management.

\begin{tabular}{|c|c|c|c|c|c|}
\hline \multirow[b]{2}{*}{ Group or indicator } & \multirow{2}{*}{$\begin{array}{l}\text { Specific weight } \\
\text { of the group or } \\
\text { indicator, } \%\end{array}$} & \multicolumn{2}{|c|}{ Threshold value in points } & \multicolumn{2}{|c|}{$\begin{array}{l}\text { The conditions for the } \\
\text { reduction of points }\end{array}$} \\
\hline & & minimum & maximum & $\begin{array}{c}\text { The norm } \\
\text { of } \\
\text { indicator }\end{array}$ & $\begin{array}{l}\text { The size of } \\
\text { reduction from } \\
\text { the norm }\end{array}$ \\
\hline The intensity of waste generation: & 50 & 0 & 50 & - & - \\
\hline The rationality of consumers: & 16.67 & 0 & 16.67 & - & - \\
\hline - waste generation per capita per day. & 16.67 & $1.58 \mathrm{~kg}-0$ points & $\begin{array}{c}0 \mathrm{\kappa г}-16.67 \\
\text { points }\end{array}$ & $0 \mathrm{~kg}$ & $\begin{array}{c}\text { for } 1 \mathrm{~kg}-10.55 \\
\text { points }\end{array}$ \\
\hline The rationality of producers: & 16.67 & 0 & 16.67 & - & - \\
\hline $\begin{array}{l}\text { - the industrial waste generation per } \\
\text { day. }\end{array}$ & 16.67 & $\begin{array}{l}42.62 \mathrm{~kg}-0 \\
\text { points }\end{array}$ & $\begin{array}{c}0 \mathrm{~kg}-16.67 \\
\text { points }\end{array}$ & $0 \mathrm{~kg}$ & $\begin{array}{c}\text { for } 1 \mathrm{~kg}-0.39 \\
\text { points }\end{array}$ \\
\hline The efficiency of the waste structure: & 16.67 & 0 & 16.67 & - & - \\
\hline $\begin{array}{l}\text { - the proportion of plastic waste (in } \\
\text { total waste). }\end{array}$ & 16.67 & $100 \%-0$ points & $\begin{array}{l}0 \%-16.67 \\
\text { points }\end{array}$ & $0 \%$ & $\begin{array}{c}\text { for } 1 \%- \\
0.17 \text { points }\end{array}$ \\
\hline The efficiency of waste utilization: & 50 & 0 & 50 & - & - \\
\hline $\begin{array}{l}\text { The efficiency of waste sorting and } \\
\text { collection: }\end{array}$ & 12.5 & 0 & 12.5 & - & - \\
\hline - level of waste collection; & 12.5 & $0 \%-0$ points & $\begin{array}{c}100 \%-12.5 \\
\text { points }\end{array}$ & $100 \%$ & $\begin{array}{c}\text { for } 1 \%- \\
0.13 \text { points }\end{array}$ \\
\hline $\begin{array}{l}\text { The efficiency of the utilization } \\
\text { methods: }\end{array}$ & 12.5 & 0 & 12.5 & - & - \\
\hline $\begin{array}{l}\text { - the share of recycling among all } \\
\text { utilization methods; }\end{array}$ & 4.17 & $0 \%-0$ points & $\begin{array}{c}29 \%-4.17 \\
\text { points }\end{array}$ & $29 \%$ & $\begin{array}{c}\text { for } 1 \%-0.14 \\
\text { points }\end{array}$ \\
\hline $\begin{array}{l}\text { - the share of open landfills among } \\
\text { all utilization methods; }\end{array}$ & 4.17 & $100 \%-0$ points & $\begin{array}{c}0 \%-4.17 \\
\text { points }\end{array}$ & $0 \%$ & $\begin{array}{c}\text { for } 1 \%-0.14 \\
\text { points }\end{array}$ \\
\hline $\begin{array}{l}\text { - minimum level recycling costs } \\
\text { among other methods. }\end{array}$ & 4.17 & $\begin{array}{l}\text { from } 2 \text { places or } \\
\text { more }-0 \text { points }\end{array}$ & $\begin{array}{c}1 \text { place }-4.17 \\
\text { points }\end{array}$ & 1 place & $\begin{array}{l}\text { for } 1 \text { place - } \\
4.17 \text { points } \\
\end{array}$ \\
\hline $\begin{array}{l}\text { Level of waste management } \\
\text { coverage: }\end{array}$ & 12.5 & 0 & 12.5 & - & - \\
\hline $\begin{array}{l}\text { - percentage of countries } \\
\text { implementing waste laws and } \\
\text { recommendations; }\end{array}$ & 12.5 & $0 \%-0$ points & $\begin{array}{c}100 \%-12.5 \\
\text { points }\end{array}$ & $100 \%$ & $\begin{array}{c}\text { for } 1 \%-0.13 \\
\text { points }\end{array}$ \\
\hline $\begin{array}{l}\text { Efficiency of waste payment load } \\
\text { distribution: }\end{array}$ & 12.5 & 0 & 12.5 & - & - \\
\hline $\begin{array}{l}\text { - gap of waste management fees } \\
\text { between households and businesses; }\end{array}$ & 3.13 & $\begin{array}{l}4.52 \text { per unit }-0 \\
\text { points }\end{array}$ & $\begin{array}{l}1 \text { per unit - } \\
3.13 \text { points }\end{array}$ & 1 per unit & $\begin{array}{l}\text { for } 1 \text { per unit - } \\
0.89 \text { points } \\
\end{array}$ \\
\hline $\begin{array}{l}\text { - percentage of municipal } \\
\text { expenditures on waste management; }\end{array}$ & 3.13 & $19 \%-0$ points & $\begin{array}{c}4 \%-3.13 \\
\text { points }\end{array}$ & $4 \%$ & $\begin{array}{c}\text { for } 1 \%- \\
0.21 \text { points }\end{array}$ \\
\hline $\begin{array}{l}\text { - waste management fee type and } \\
\text { billing method by household's per } \\
\text { volume waste; }\end{array}$ & 3.13 & $0 \%-0$ points & $\begin{array}{c}47 \%-3.13 \\
\text { points }\end{array}$ & $47 \%$ & $\begin{array}{l}\text { for } 1 \%- \\
0.07 \text { points }\end{array}$ \\
\hline $\begin{array}{l}\text { - waste management fee type and } \\
\text { billing method by commercial's size } \\
\text { or type. }\end{array}$ & 3.13 & $0 \%-0$ points & $\begin{array}{c}33 \%-3.13 \\
\text { points }\end{array}$ & $33 \%$ & $\begin{array}{c}\text { for } 1 \%- \\
0.09 \text { points }\end{array}$ \\
\hline $\begin{array}{l}\text { Overall efficiency of waste } \\
\text { management }\end{array}$ & 100 & 0 & 100 & - & - \\
\hline
\end{tabular}

related only to utilization. According to the authors, in order to achieve a balance between inflows and outflows of waste, factors related to both waste generation and utilization must be taken into account simultaneously in an integrated indicator - the overall efficiency of waste management.

Indicators proposed for the intensity of waste generation are:

- The waste generation per capita per day showing the rationality of consumers in relation to waste;

- The industrial waste generation per day characterizing the rationality of producers;
- The proportion of plastic waste in total waste responsible for the efficiency of the waste structure.

It should be noted that the proportion of plastic waste, rather than other types of waste (such as paper, metal, glass, food, etc.) is chosen as an indicator, because according to the World Bank, in all countries plastic waste occupies the largest fraction of waste generated.

The group of factors used to characterize the efficiency of utilization which consists of 12 indicators (see Table 1). Table 1 presented the author's assessment of the effectiveness of waste management, which 
Table 2. Data for calculating waste management efficiency points for countries around the world, depending on their income for 2018.

\begin{tabular}{|c|c|c|c|c|}
\hline \multirow{2}{*}{ Group or indicator } & \multicolumn{4}{|c|}{ Level income GDP per capita } \\
\hline & Low & Lower-middle & Upper-middle & High \\
\hline The intensity of waste generation: & - & - & - & - \\
\hline The rationality of consumers: & - & - & - & - \\
\hline - waste generation per capita per day, kg. & 0.4 & 0.53 & 0.69 & 1.58 \\
\hline The rationality of producers: & - & - & - & - \\
\hline - the industrial waste generation per day, kg. & 0.1 & 0.36 & 5.72 & 42.62 \\
\hline The efficiency of the waste structure: & - & - & - & - \\
\hline - the proportion of plastic waste (in total waste), $\%$. & 56 & 53 & 54 & 32 \\
\hline The efficiency of waste utilization: & - & - & - & - \\
\hline The efficiency of waste sorting and collection: & - & - & - & - \\
\hline - level of waste collection, $\%$ & 39 & 51 & 82 & 96 \\
\hline The efficiency of the utilization methods: & - & - & - & - \\
\hline - the share of recycling among all utilization methods, $\%$; & 3.7 & 6 & 4 & 29 \\
\hline - the share of incineration among all utilization methods, $\%$ & 0 & 0.1 & 10 & 22 \\
\hline - the share of open landfills among all utilization methods, $\%$; & 93 & 66 & 30 & 2 \\
\hline $\begin{array}{l}\text { - rating of minimum level recycling costs per ton among other } \\
\text { methods, place. }\end{array}$ & 3 & 2 & 1 & 1 \\
\hline Level of waste management coverage: & - & - & - & - \\
\hline $\begin{array}{l}\text { - percentage of countries implementing waste laws and } \\
\text { recommendations; }\end{array}$ & 60 & 89 & 84 & 96 \\
\hline Efficiency of waste payment load distribution:: & - & - & - & - \\
\hline $\begin{array}{l}\text { - gap of waste management fees between households and businesses, } \\
\text { per unit; }\end{array}$ & 4.20 & 3.68 & 4.52 & 1.87 \\
\hline - percentage of municipal expenditures on waste management, \%; & 19 & 11 & 11 & 4 \\
\hline $\begin{array}{l}\text { - waste management fee type and billing method by household's per } \\
\text { volume waste, \%; }\end{array}$ & 20 & 4 & 9 & 47 \\
\hline $\begin{array}{l}\text { - waste management fee type and billing method by commercial's } \\
\text { size or type, } \% \text {. }\end{array}$ & 0 & 6 & 22 & 33 \\
\hline
\end{tabular}

included the factors listed above and the criteria for calculating points.

The indicator of the share of recycling among all utilization methods is selected for evaluation, since the UN concept of "Sustainable development" states a goal by 2030 to increase the recycling of waste and the use of waste biodegradation. The share of open landfills among all utilization methods is also related to the group of factors responsible for the efficiency of utilization methods. This indicator is selected for evaluation, since this method of utilization is dangerous to the environment and to the health of the country's population. Another indicator of the efficiency of the utilization methods that the authors selected is the minimum level of recycling costs among other methods used in the country.

The calculation of points to characterize the effectiveness of waste management used a statistical method of scoring. Each of the 12 selected indicators is assigned points according to the numerical scale developed by the authors. Both groups of waste management efficiency factors of the intensity of waste generation and the efficiency of waste utilization received the same rank of significance. The specific weight of each group is $50 \%$ for a total $100 \%$.
Within the "Intensity of waste generation" group, each of the 3 subgroups received the same significance rank.

Therefore, the share of each of the three groups of "Intensity of waste generation" is approximately $16.67 \%$, which is $50 \%$ in total. Within the "Efficiency of waste utilization" group, each of the 4 subgroups received the same significance rank. Therefore, the share of each subgroup in "Efficiency of waste utilization" is equal to $12.5 \%$, which is $50 \%$ in total. Within the "Efficiency of waste utilization methods" subgroup, each of the 3 indicators received the same significance rank. Therefore, the share of each indicator is approximately $4.17 \%$, for a total of $12.5 \%$. Within the "Efficiency of waste payment load distribution" subgroup, each of the 4 indicators received the same significance rank. Therefore, the share of each indicator is approximately $3.13 \%$, for a total of $12.5 \%$

The number of points for each of the waste performance indicators depends on the specific weights set above. The maximum value of the score scale is the maximum specific weight of the indicator, and the minimum value of the scale is 0 points. 
Table 3. Calculation of the effectiveness of waste management by income of level for 2018 in the world, points.

\begin{tabular}{|c|c|c|c|c|}
\hline \multirow{2}{*}{ Group or indicator } & \multicolumn{4}{|c|}{ Level income GDP per capita } \\
\hline & Low & Lower-middle & Upper-middle & High \\
\hline The intensity of waste generation: & 36 & 35 & 31 & 11 \\
\hline The rationality of consumers: & 12 & 11 & 9 & 0 \\
\hline - waste generation per capita per day. & 12 & 11 & 9 & 0 \\
\hline The rationality of producers: & 17 & 17 & 14 & 0 \\
\hline - the industrial waste generation per day. & 17 & 17 & 14 & 0 \\
\hline The efficiency of the waste structure: & 7 & 8 & 8 & 11 \\
\hline - the proportion of plastic waste (in total waste). & 7 & 8 & 8 & 11 \\
\hline The efficiency of waste utilization: & 15 & 23 & 33 & 48 \\
\hline The efficiency of waste sorting and collection: & 5 & 6 & 10 & 12 \\
\hline - level of waste collection; & 5 & 6 & 10 & 12 \\
\hline The efficiency of the utilization methods: & 1 & 2 & 8 & 12 \\
\hline - the share of recycling among all utilization methods; & 4 & 1 & 1 & 1 \\
\hline - the share of open landfills among all utilization methods; & 0 & 1 & 3 & 4 \\
\hline - minimum level recycling costs among other methods. & 0 & 0 & 4 & 4 \\
\hline Level of waste management coverage: & 8 & 11 & 11 & 12 \\
\hline $\begin{array}{l}\text { - percentage of countries implementing waste laws and } \\
\text { recommendations; }\end{array}$ & 8 & 11 & 11 & 12 \\
\hline Efficiency of waste payment load distribution: & 2 & 3 & 4 & 12 \\
\hline - gap of waste management fees between households and businesses; & 0 & 1 & 0 & 2 \\
\hline - percentage of municipal expenditures on waste management; & 0 & 2 & 2 & 3 \\
\hline $\begin{array}{l}\text { - waste management fee type and billing method by household's per } \\
\text { volume waste; }\end{array}$ & 1 & 0 & 1 & 3 \\
\hline $\begin{array}{l}\text { - waste management fee type and billing method by commercial's size } \\
\text { or type. }\end{array}$ & 0 & 1 & 2 & 3 \\
\hline Overall efficiency of waste management & 51 & 58 & 64 & 59 \\
\hline
\end{tabular}

The conditions for reducing each of the 12 indicators were presented in table 1 . The calculation of the point's reduction was performed using the following formula 1 :

$$
\mathrm{D}_{\mathrm{i}}=\frac{\mathrm{W}_{\mathrm{i}}}{\Delta \mathrm{I}}
$$

$D_{i}-$ the size of the reduction of the indicator from the norm by $1 \%$, points; $\mathrm{W}_{\mathrm{i}}-$ specific weight of the indicator, $\% ; \Delta \mathrm{I}-$ difference between the maximum and minimum threshold value of the indicator.

Table 2 presented the data grouped by the authors for calculating waste management efficiency scores for countries around the world based on data from table 1 and the World Bank report "What a Waste 2.0" for 2018.

The results of the approbation of the evaluating the effectiveness of waste management was presented for four groups of countries, depending on the level of per capita income as of 2018 in table 3 (it was based on data from table 2 and the calculation criteria of table 1).

In table 3 , countries with upper middle income per capita (64 points) ranked first place of overall efficiency of waste management ( 64 points).

Countries with high income per capita ranked first place of efficiency of waste utilization (48 points).

Countries with low income per capita were the leaders of intensity of waste generation (36 points).

In addition to the overall efficiency of waste management in countries, it is necessary to maintain a balance between inflows and outflows of waste [24], [25], [26].

Figure 2 summarizes all indicators of efficiency of waste management for the world's countries for 2018 (based on table 2).

The authors calculated the waste balance for each group of countries using the formula 2 :

$$
\mathrm{B}_{\mathrm{w}}=\mathrm{I}_{\mathrm{g}}-\mathrm{E}_{\mathrm{u}}
$$

$\mathrm{B}_{\mathrm{W}}$ - the balance of waste, points; $\mathrm{I}_{\mathrm{g}}$ - the intensity of waste generation, points; $\mathrm{E}_{\mathrm{u}}$ - the efficiency of waste utilization, points.

From the point of view of waste management, according to our hypothesis, the most effective country (that is, the waste management policy is proportional) is considered to be the country where the difference between the intensity of waste generation and the efficiency of waste utilization is the smallest and the system is closed to equilibrium. 


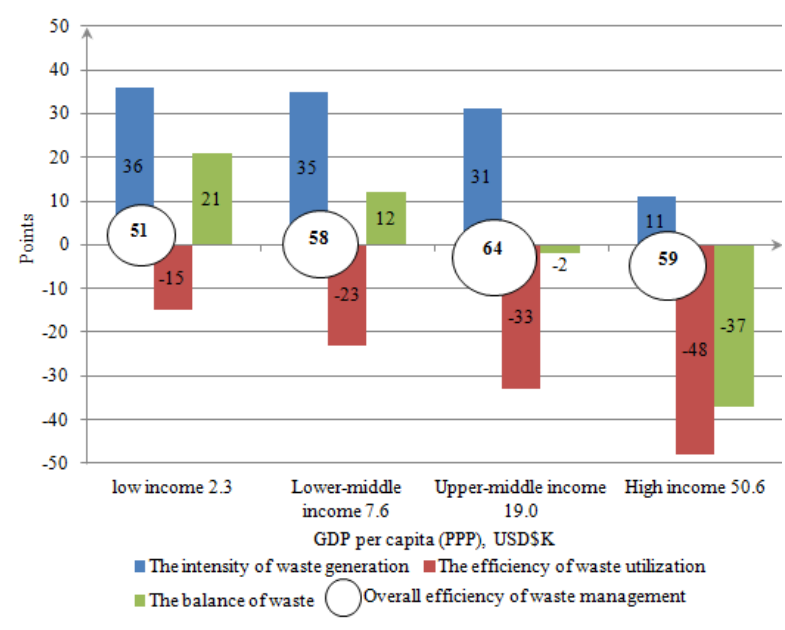

Fig. 2. Efficiency of waste management, depending on the level of income per capita in the countries of the world for 2018.

There may also be a deficit or surplus of the waste balance in the country, which means that the waste management policy is one-sided (disproportional).

For clarity, indicators of efficiency of waste utilization (associated with reduced waste) were marked with a minus sign, and the indicators of efficiency of waste generation (associated with increased waste) were marked with a plus sign.

\section{Discussion}

Thus, the conclusions were drawn from the calculated indicators of balance for waste management (formula 2) presented in figure 2 .

The minimum difference in the balance of the waste (equilibrium) was observed in countries with upper middle income (- 2 points). In these countries less generated less waste was generated due to lower growth rates of industrial production and consumption. This leads to a relative equality of the waste balance (the intensity of waste generation and the efficiency of waste utilization).

There is a significant imbalance associated with the lack of waste disposal in the countries with low-income (+23 points) and in the countries with lower-middle income (+12 points). It is important not to reduce the intensity of waste generation, but to increase the efficiency of waste utilization.

A negative imbalance of waste is observed in countries with high-income ( -37 points). In these countries, uneven policies in the waste management are directed mainly towards the efficiency of waste utilization creating this imbalance. It is necessary to work on reducing the amount of waste generated by households and industrial production.

The authors calculated the coefficient of correlation between the countries' incomes and the overall efficiency of waste management for 2018, it was 0.38 . This means that the overall efficiency of waste management did not depend on revenue growth, since the coefficient of correlation is less than was 0.5 .

The coefficient of correlation between a country's per capita income and the efficiency of waste utilization was 0.97 for 2018. It showed that the efficiency of waste utilization increases with the growth of the country's per capita income.

The coefficient of correlation between the country's per capita income and the intensity of waste generation was 0.99 for 2018. This means that as the country's per capita income increases, the amount of waste increases.

Thus, the hypothesis put forward by the authors that the effectiveness of waste management depends from level of income per capita was confirmed.

The practical significance of the study is that depending on the level of per capita income, the waste management policy should be differentiated. Thus, highly developed countries should focus not only on waste utilization, but also should work to reduce the rate of waste generation. According to an old of Russian proverb "The clean is not where they clean, but where they do not litter".

Countries with low and low middle income should disseminate the progressive experience of developed countries in waste management, focusing primarily on recycling rather than incineration. All this will allow these countries to maintain low rates of waste generation and prevent rapid pollution of their territories.

Prospects for research: in order to form an effective waste management policy, it is necessary to shift the emphasis toward maintaining a balance between the intensity of waste generation and its utilization. The intensive development of waste utilization increases the burden on the environment, so sustainable development, in our opinion, is associated with the need to increase attention to reducing the volume of waste generation.

\section{Conclusion}

The development of industrial production led to the launching of a consumer economy. The need to switch to the "Circular economy" leads to increased attention to the formation of a balanced policy for all resources [27], [28], [29].

In our opinion, investments in human capital are beginning to acquire special relevance. Changing the attitude of the population toward resources and the ecology of its territory will lead to the gradual reduction in unrestrained consumption of the today's period of economic development. The awareness of the need for careful treatment of resources can become a driver for the formation of a balanced waste management policy.

We would like to thank Professor Phillip Sanger of Purdue University (USA) for reviewing the article.

\section{References}

[1] H. Terefe, B.W. Dullo, Evolution of waste management strategies in industries: from passive to proactive, International journal of environment and waste management, 3, 3, 84-90 (2015).

[2] H. Abaza, et al., Green Economy in action: Articles and excerpts that Illustrate Green 
Economy and Sustainable Development Efforts (2012) [Electronic resource]. Available at: https://www.un.org/waterforlifedecade/pdf/green economy_in_action_eng.pdf.

[3] M. Porter, C. Van der Linde, Toward a new conception of the environment-competitiveness relationship, Journal of Economic Perspectives, 9, 4, 97-118 (1995).

[4] W.B. Gray, Environmental regulations and business decisions, IZA World of Labor, 1-10 (2015).

[5] S. Duarte, V. Cruz-Machado, Exploring linkages between Lean and Green supply chain and the industry 4.0., International conference of management science and engineering management, 1242-1252 (2017).

[6] M. Dieste, R. Panizzolo, The effect of lean practices on environmental performance: an empirical study, Lean engineering for global development, 225-258 (2019).

[7] W.D. Leong, H.L. Lam, P.Q. Wendy, et al., Lean and green manufacturing - a review on its applications and impacts, Process integration and optimization for sustainability, 3, 5-23 (2019).

[8] M.K. Mishra, D. Choudhury, V.G. Rao, Theoretical economics letters, Impact of SMEs green supply chain practice adoption on SMEs firm and environmental performance, 6, 9, 19011919 (2019).

[9] M.F. Abreu, A.C. Alves, F. Moreira, . The leangreen BOPSE indicator to assess efficiency and sustainability, Lean engineering global development, 259-291 (2019).

[10] S. Duarte, V. Cruz-Machado, Green and lean model for business sustainability, Proceedings of the Tenth international conference on management science and engineering management, 1281-1291 (2016).

[11] Ch. Chen, T. Park, X. Wang, et al., China and India lead in greening of the world through land use management Nature sustainability, 2, 122-129 (2019).

[12] T. Larson, R. Greenwood, Perfect complements: synergies between lean production and ecosustainability initiatives, Environmental Quality Management, 13, 4, 27-36 (2004).

[13] A.A. King, M.J. Lenox, Lean and Green? An empirical examination of the relationship between lean production and environmental performance, Production and operation management, 10, 3, 244-256 (2001).

[14] G.G. Bergmiller, P.R. McCright, Parallel models for lean and green operations, Proceedings of the 2009 Industrial Engineering Research Conference, 1, 1, 22-26 (2009).

[15] Ch.M. Kim, H.T. Ming Lim, Journal of cleaner production, Green as the new Lean: how to use Lean practices as a catalyst to greening your supply chain, 40, 93-100 (2013).

[16] J.D. Hanson, S. Melnyk, R.J. Calantone, Greener management international, Core values and environmental management: a strong inference approach, 46, 29-40 (2004).

[17] J.D. Hanson, S. Melnyk, R.J. Calantone, Strategic sustainability: The state of the art in corporate environmental management systems, Core values and environmental management: A strong inference approach, pp.91-103 (2017).

[18] The website of the World Bank [Electronic resource]. Available at: https://data.worldbank. org/indicator/NY.GDP.MKTP.PP.CD.

[19] Report "What a Waste 2.0" of International Bank for Reconstruction and Development (2018) [Electronic resource]. Available at: https:// openknowledge.worldbank.org/bitstream/handle/1 0986/30317/211329ov.pdf?sequence $=$.

[20] S. Ko, W. Kim, S. Shin, J. Shin, The economic value of sustainable recycling and waste management policies: The case of a waste management crisis in South Korea, Waste Management, 104, 1, 220-227 (2020).

[21] V.G. Mikhailov, N.N. Golofastova, T.V. Galanina, Environmental-economic assessment of generation, flow and efficiency of use of production and consumption waste, IOP Conference Series Earth and Environmental Science, 50, 1 (2017).

[22] H. Han, Z. Zhang, S. Xia, Sustainability, The crowding-out effects of garbage fees and voluntary source separation programs on waste reduction: evidence from China, 8, 7 (2016).

[23] E. Amasuomo, J. Baird, The concept of waste and waste management, Journal of Management and Sustainability, 4, 6, 88-96 (2016).

[24] S. Shankar, R. Khandelwal, Sustainable waste management strategy for a campus: a case study of JUET, Management of environmental quality an international journal, Guna, 28, 610-623 (2017).

[25] P. Ghisellini, C. Cialani, S. Ulgiati, A review on circular economy: The expected transition to a balanced interplay of environmental and economic systems, Journal of cleaner production, 114, 7, 11-32 (2016).

[26] S. Sakai, J. Yano, Y. Hirai, et al., Waste prevention for sustainable resource and waste management, Journal of material cycles and waste management, 19, 1295-1313 (2017).

[27] M. Saita, M.V. Franceshelli, The role of waste management in the Green economy, Sustainable Entrepreneurship and Investments in the Green Economy, 169-199 (2017).

[28] R. Cobra, M. Guadia, G. Queiroz, et al., "Waste" as the common "Gene" connecting cleaner production and Lean Manufacturing: A proposition of a hybrid definition, Environmental quality management, 25, 25-40 (2016).

[29] I. Zvarych, Circular economy and globalized waste management, Journal of European economy, 16, 1, 38-53 (2017). 